Ekonomia - Wroclaw Economic Review 23/1 (2017)

Acta Universitatis Wratislaviensis

No 3754

DOI: 10.19195/2084-4093.23.1.10

\author{
Marek Marchewka \\ Uniwersytet Marii Curie Skłodowskiej w Lublinie \\ marekmarchewka68@wp.pl
}

\title{
Weterani poszkodowani. Rzeczywistość życia po powrocie z misji
}

\author{
JEL Classification: Z00, K00, I14
}

Keywords: Injured veterans, combat mission, stabilization mission, disabled, Law on Veterans

\section{Abstract \\ Injuried veterans. The reality of life after returning from a mission}

This publication is devoted to problems of veterans injured returnees to the country after missions beyond the borders of our state. Polish military missions have existed for over 60 years. It was a total of 80 operations and foreign missions in wich participated our soldiers and military personnel. Over those 60 years did not return to the country in 1142 participants, including 22 killed in Iraq and 39 in Afghanistan. The first three Polish soldiers were killed in 1955 in a helicopter crash in Korea. They were using the language of military losses irreversible, but in addition to the dead, we must realize that in the course of carring out their duties in additions to the dead and wounded are also victims who return to the homeland. During the operations in the Middle East were injured 500 Poles. 10 years of polish participation in the Afghan war victims have been injured and more than 600 injured, 300 seriously injured. What the Polish state mode to compensate former participants of the mission their services abroad, when they became veterans injured. Undoubtedly step facing front of the long term expectations of many victims of the Mission is the Act 19 August 2011 by veterans of activities outside the country, wich is decidated to this publication.

\section{Wprowadzenie}

Celem niniejszego artykułu jest przedstawienie rzeczywistości życia żołnierzy zawodowych (weteranów poszkodowanych) powracających z misji zagranicznych do kraju oraz działań rządu RP nadającego prawa i przywileje uczestnikom misji poza granicami kraju, status weterana poszkodowanego. Największy nacisk skierowano na przedstawienie pozytywnych zmian, jakie się dokonały na rzecz poprawy egzystencji powracających po misji weteranów poszkodowanych oraz omówienie kluczowych przywilejów wynikających z ustawy z dnia 19 sierpnia 
2001 r. Analizą zostało objęte szerokie spektrum zagadnień: świadczenia opieki zdrowotnej, pomoc psychologiczna, pomoc w finansowaniu nauki i uprawnienia socjalne, uprawnienia pracownicze, dodatek weterana poszkodowanego, źródła i sposób finansowania niektórych świadczeń. Podstawowym celem pracy jest zbadanie ważniejszych przywilejów, mających duże znaczenie dla weteranów poszkodowanych wynikających z ustawy z dnia 19 sierpnia 2011 r. Dz.U. z 2011 r. $\mathrm{Nr}$ 205, poz. 1203 o weteranach działań poza granicami państwa. W związku $\mathrm{z}$ realizacją powyższych celów w pracy weryfikacji zostanie poddanych kilka hipotez badawczych. Przyjęto główną supozycję, że rok 2011 stał się przełomowy dla rzeszy członków misji powracających do kraju i uzyskujących status weterana poszkodowanego. Chodzi tu przede wszystkim o pozyskanie wielu przywilejów, o których nie było mowy we wcześniejszych latach. Przyjęto też hipotezę, iż oprócz przywilejów dla weteranów poszkodowanych pewne korzyści otrzymali też uczestnicy misji niebędący poszkodowanymi. Chodzi tu między innymi z możliwości skorzystania $\mathrm{z}$ rehabilitacji w sanatoriach, po wcześniejszej opinii lekarza wojskowego oraz psychologa. Kolejna hipoteza zakłada, że mimo przysługujących przywilejów uczestnicy misji muszą często stawić czoła problemom i zmagać się z trudnościami natury biurokratycznej w egzekwowaniu należących im przywilejów.

\section{Teoretyczny aspekt badań}

W ciągu lat powstawało wiele prac poruszających problematykę udziału żołnierzy polskich w misjach poza granicami naszego kraju, na przykład Operacje pokojowe ONZ Leszka Zapałowskiego, Afganistan. Gdzie reguta jest brak regut Krzysztofa Korzeniowskiego, a także wiele innych interesujących opracowań tegoż autora dotyczących misji zagranicznych, czy też Polacy w stużbie pokoju 1953-2003 (Agencja Wydawnicza CB, Warszawa 2003). Prace te są bogatym źródłem wiedzy na temat odbywających się misji. Autor niniejszej publikacji podjął się poruszyć temat bardzo jemu bliski, to znaczy; Weterani poszkodowani. Rzeczywistość życia po powrocie z misji. Autor ciągle jeszcze służy w siłach zbrojnych i spotyka się na co dzień z weteranami oraz weteranami poszkodowanymi.

\section{Metodologia badań}

Przy realizacji podjętego problemu badawczego zostały zastosowane różne metody badawcze. W kompleksowych badaniach nad omawianą problematyką użyto metody wywiadu i obserwacji, która okazała się najbardziej przydatną w trakcie analiz i genezy rzeczywistości życia poszkodowanych po powrocie z misji. Reali- 
zując wyżej wymieniony cel badawczy, przeprowadzono siedem wywiadów techniką wywiadu nieskategoryzowanego. Podmiotem badań byli żołnierze zawodowi 3 Brygady Zmechanizowanej w Lublinie. Wywiady odbywały się po zakończeniu misji w Iraku i Afganistanie (jeden uczestnik wywiadu brał udział czterokrotnie w misji w Afganistanie, obecnie ma status weterana poszkodowanego i służy w tej samej jednostce wojskowej co autor publikacji). Niezastąpiona była też metoda analizy treści, polegająca na przybliżeniu bardzo ważnych przywilejów uzyskanych przez wprowadzenie tak znaczącej ustawy dla weteranów poszkodowanych.

\section{Charakterystyka działań misyjnych}

Żołnierze polscy już od kilkudziesięciu lat uczestniczą w misjach poza granicami naszego kraju. Na początku były to misje wywodzące się z kraju o innym ustroju politycznym — Polski socjalistycznej. Po przełomie politycznym po roku 1989 stopniowo zmieniał się charakter misji z misji obserwacyjnych na misje bojowe, stabilizacyjne i szkoleniowe. Praca ta jest poświęcona weteranom poszkodowanym, a w szczególności ich przywilejom nadanym w ustawie utworzonej dopiero w roku 2011. Autor uznał, iż jako uczestnik dwóch misji, tj. obserwacyjnej w Syrii w latach 1995-1996 oraz misji stabilizacyjnej w Kosowie w 2000 roku, miał prawo do wyrobienia pewnego poglądu na kwestie dotyczące życia uczestników powracających z różnych zakątków świata i borykających się z różnymi trudnościami życia codziennego w swych jednostkach.

Podczas operacji wojskowej na Bliskim Wschodzie poszkodowanych i rannych zostało 500 Polaków. Przez 10 lat udziału Polski w afgańskiej wojnie poszkodowanych zostało 800 Polaków, w tym ponad 350 rannych.

Autor niniejszej publikacji uważa, iż jego obserwacje na konkretnych przykładach w pewnym stopniu wzbogacą i zainteresują pewną grupę osób zainteresowanych tą tematyką.

Pełniąc służbę w 3 Brygadzie Legionów im gen. broni Leona Berbeckiego, autor był świadkiem wyjazdów wielu żołnierzy z jego brygady na misje bojowe do Iraku oraz Afganistanu. Widział i rozmawiał wielokrotnie z poszkodowanymi powracającymi z rejonu misji, poznając ich opinie i życie po powrocie z misji. Rozmawiał osobiście z ludźmi okaleczonymi w trwających działaniach wojennych. Byli to między innymi:

- mł. chor. Robert Ciszewski (wybuch ładunku podłożony pod przejeżdżający pojazd patrolowy urwał mu prawą rękę; obecnie ma założoną protezę);

— sierż. Sylwester Wręga (wybuch ładunku uszkodził mu słuch).

Znani są także autorowi koledzy, którzy mieli mniej szczęścia i polegli w rejonie misji:

— kpt. Sławomir Stróżak — autor pełnił z nim misję w Kosowie w 2000 r.; z Iraku już nie powrócił do kraju; 
— plut. Andrzej Filipek, kierowca pojazdu opancerzonego Hummer — zginął na miejscu po wybuchu ładunku pod kołami pojazdu.

Obecnie autor utrzymuje przyjacielskie stosunki z kilkoma weteranami poszkodowanymi.

Z pytań do tych, którzy powrócili, oraz w luźnych rozmowach dotyczących rzeczywistości ich życia po misji, można wysunąć odpowiednie wnioski. Większość z nich wskazywała, że ich problemy zaczęły pojawiać się po powrocie do kraju. Przejawiały się na każdym kroku, w sposobie traktowania lub nawet braku jakiegokolwiek zainteresowania. W zapomnieniu, które sprawiło, że czują się winni temu, co ich spotkało. Nie chcą dziś wracać i wypominać konkretnym osobom czy instytucjom lekceważenia. Dziś twierdzą, że jest lepiej, chociaż i tak jeszcze wiele jest do naprawienia. Obecnie powstało i prężnie działa Stowarzyszenie Rannych i Poszkodowanych w Misjach Poza Granicami Kraju, które bardzo dobrze wywiązuje się ze swych obowiązków, organizując:

— turnusy rehabilitacyjno-sportowe w różnych miejscach kraju;

- warsztaty terapeutyczne;

— promocję kampani społecznej „Dzień Weterana — szacunek i wsparcie”;

- spływy kajakowe, na przykład w Sorkwitach koło Mrągowa (dla rannych i poszkodowanych);

- sesje egzystencjalno-duchowe dla uczestników misji poza granicami państwa (organizowane przez Caritas Ordynariatu Polowego Wojska Polskiego, we współpracy z Departamentem Komunikacji Społecznej MON).

Wszystkie te działania znacznie poprawiają egzystencję weteranów poszkodowanych — uczestników misji poza granicami kraju.

Autor skupił się na głównych przywilejach, które po wprowadzeniu nowej ustawy w znaczący sposób polepszyły funkcjonowanie osób mających status weterana poszkodowanego. Ustawa o weteranach weszła w życie stosunkowo niedawno. Wcześniej nie było żadnego aktu prawnego, który regulowałby status weterana. Ustawa ta jest bardzo istotna dla wszystkich rannych i poszkodowanych w misjach poza granicami państwa.

\section{Status weterana poszkodowanego}

Artykuł 3 ustawy z dnia 19 sierpnia 2011r. definiuje kto jest weteranem poszkodowanym.

Weteranem poszkodowanym poza granicami państwa, zwanym dalej „,weteranem poszkodowanym" może być osoba, która biorąc udział na podstawie skierowania w działaniach poza granicami państwa, doznała uszczerbku na zdrowiu wskutek wypadku pozostającego w związku z tymi działaniami lub choroby nabytej podczas wykonywania zadań lub obowiązków służbowych poza granicami państwa, z tytułu których przyznano jej świadczenia odszkodowawcze. 
Podstawą do ubiegania się o przyznanie statusu weterana poszkodowanego są:

— wniosek zainteresowanego do Ministra Obrony Narodowej;

— zaświadczenie wydane odpowiednio przez dowódcę jednostki wojskowej, w której żołnierz ostatnio pełnił lub pełni służbę;

— zaświadczenie z Krajowego Rejestru Karnego;

— protokół powypadkowy albo decyzja o stwierdzeniu choroby zawodowej;

— orzeczenie właściwej komisji lekarskiej o związku uszczerbku na zdrowiu $\mathrm{z}$ wypadkiem pozostającym $\mathrm{w}$ związku $\mathrm{z}$ działaniami poza granicami państwa lub chorobą nabytą podczas wykonywania zadań lub obowiązków służbowych w ramach działań poza granicami państwa albo orzeczenie lekarza orzecznika lub komisji lekarskiej Zakładu Ubezpieczeń Społecznych, ustalające uszczerbek na zdrowiu w związku z wypadkiem przy pracy lub chorobą zawodową, wydane dla celów świadczeń z ubezpieczenia społecznego;

- decyzja administracyjna o przyznaniu świadczeń odszkodowawczych albo prawomocny wyrok sądu zasądzający odszkodowanie.

Dokumentem potwierdzającym status weterana poszkodowanego jest legitymacja weterana poszkodowanego wydana przez Ministra Obrony Narodowej. Legitymację wydaje się w terminie 60 dni od dnia decyzji ostatecznej o przyznaniu statusu weterana poszkodowanego.

\section{Uhonorowanie}

Rozdział 2 ustawy zatytułowany ustanawia dzień 29 maja Dniem Weterana Działań poza Granicami Państwa.

Minister Obrony Narodowej, za rany i kontuzje odniesione podczas działań poza granicami państwa, może przyznać weteranowi i poszkodowanemu-żołnierzowi wojskowa odznakę „Za Rany i Kontuzje”.

W artykule 17 ustawy ustanawia się odznakę honorową „Za zasługi w działaniach poza granicami Rzeczypospolitej Polskiej”.

Artykuł 18 ustawy wprowadza odznakę honorową „Za zasługi w zapewnieniu bezpieczeństwa państwa poza granicami Rzeczpospolitej Polskiej" (dotyczy weterana-funkcjonariusza ABW).

Kolejnymi artykułami nadającymi przywileje tej grupie uczestników misji, to artykuł 19 dający prawo weteranom poszkodowanym do noszenia umundurowania oraz odznak i odznak wojskowych w przypadku zwolnienia z czynnej służby wojskowej, którym w czasie pełnienia służby nie przysługiwały należności mundurowe i wyekwipowania wyjściowego. Mają oni prawo do jednorazowego bezpłatnego otrzymania takiego umundurowania i wyekwipowania oraz artykuł 20: weteranom poszkodowanym daje prawo do zwrotu kosztów przejazdu, z uwzględnieniem przysługujących mu ulg $\mathrm{w}$ tym zakresie i zakwaterowania, poniesionych w związku z udziałem w uroczystościach organizowanych odpowiednio przez: 
- Ministra Obrony Narodowej;

— dowódcy jednostki wojskowej (zwrot kosztów przysługuje za udział w nie więcej niż dwóch uroczystościach w danym roku kalendarzowym, łącznie do wysokości najniższej emerytury).

\section{4. Świadczenia opieki zdrowotnej i pomoc psychologiczna}

\section{Artykuł 23.}

Ustawa daje weteranom poszkodowanym oraz najbliższym członkom rodzin możliwość korzystania poza kolejnością z bezpłatnej pomocy psychologicznej udzielanej przez psychologów w jednostkach wojskowych oraz przez wojskowe pracownie psychologiczne, a także udzielanej w zakładach opieki zdrowotnej utworzonych i nadzorowanych przez Ministra Obrony Narodowej, jeżeli problemy zdrowotne żołnierza są związane z działaniami poza granicami państwa.

W artykule 24 ustawodawca daje prawo weteranom poszkodowanym do umieszczania poza kolejnością w domu weterana, funkcjonującego jako zakład opiekuńczo-leczniczy w ramach zakładu opieki zdrowotnej albo jako inna jednostka organizacyjna takiego zakładu i odpłatnego w nim pobytu.

Rozdział 4 obejmuje zagadnienia dotyczące pomocy $\mathrm{w}$ finansowaniu nauki oraz uprawnienia socjalne.

W artykule 26 Weteran poszkodowany-żołnierz ma prawo do uzyskania pomocy finansowej na jedną z wymienionych form kształcenia:

- naukę na poziomie szkoły ponadgimnazjalnej;

- studia pierwszego stopnia;

- studia drugiego stopnia;

— jednolite studia magisterskie;

- studia podyplomowe.

W ramach tej pomocy mogą być pokryte koszty:

- opłata za naukę lub studia;

— przejazdów z miejsca zamieszkania weterana poszkodowanego-żołnierza do szkoły lub uczelni i z powrotem;

- zakwaterowania w miejscowości, w której weteran poszkodowany-żołnierz pobiera naukę lub odbywa studia (do wysokości 400\% najniższej emerytury).

Wysokość pomocy finansowej przysługuje na każdy rok szkolny lub akademicki przez cały czas trwania nauki lub studiów, nie dłużej niż w wymiarze określonym w programie nauczania lub w programie studiów.

Weteranowi poszkodowanemu pobierającemu rentę inwalidzką z tytułu urazów lub chorób powstałych w związku z udziałem w działaniach poza granicami państwa przysługuje (art. 30):

— ulga taryfowa w wysokości 50\% przy przejazdach środkami komunikacji miejskiej; 
— ulga w wysokości 37\% przy przejazdach środkami publicznego transportu zbiorowego kolejowego i autobusowego w komunikacji krajowej w:

a) 1 i 2 klasie pociągów osobowych i pospiesznych — na podstawie biletów jednorazowych,

b) 2 klasie pociągów innych niż osobowe i pospieszne — na podstawie biletów jednorazowych.

Weteran poszkodowany-żołnierz zgodnie z artykułem 31 ustawy, który znajduje się w trudnej sytuacji materialnej, może ubiegać się o przyznanie zapomogi: na zaspokojenie potrzeb bytowych i ochronę zdrowia w wypadku choroby powodującej wzrost kosztów utrzymania, w tym zakup leków, środków opatrunkowych oraz koszty dojazdów do zakładów opieki zdrowotnej na zabiegi medyczne i rehabilitacyjne oraz usługi pielęgnacyjne niezbędne ze względu na wiek lub stan zdrowia; w przypadku zaistnienia zdarzeń losowych, mających wpływ na pogorszenie $\mathrm{w}$ istotny sposób sytuacji materialnej weterana-żołnierza lub weterana poszkodowanego-żołnierza.

\section{Uprawnienia pracownicze, dodatek weterana poszkodowanego}

Następne przywileje, które daje ustawa z dnia 19 sierpnia 2011 r. to uprawnienia pracownicze (rozdział 5.).

Weteran poszkodowany korzysta z pierwszeństwa w zatrudnieniu odpowiednio $\mathrm{w}$ jednostkach organizacyjnych podległych lub nadzorowanych przez Ministra Obrony Narodowej [...]. Okresy udziału weterana poszkodowanego w misjach poza granicami państwa wlicza się do okresu zatrudnienia, od którego zależą uprawnienia pracownicze.

Dodatek weterana poszkodowanego

Weteran poszkodowany pobierający emeryturę lub rentę inwalidzką ma prawo do dodatku weterana poszkodowanego od miesiąca złożenia wniosku do organu emerytalno-rentowego.

\section{Wnioski}

Ponad 100 tysięcy żołnierzy i funkcjonariuszy, którzy brali udział w zagranicznych misjach, uzyskało z dniem 19 sierpnia 2011 r. specjalne uprawnienia. Warunkiem nabycia tych uprawnień jest otrzymanie legitymacji weterana poszkodowanego. Obecnie liczba uprawnionych stanowi kilka tysięcy osób i stopniowo wzrasta. Dodatki do rent i emerytur, świadczenia zdrowotne poza kolejnością, zniżki na przejazdy, komunikację oraz darmową pomoc psychologiczną i dofinansowanie do nauki - to główne przywileje, które daje ustawa o weteranach. Na nowe przepisy szczególnie czekali weterani poszkodowani w czasie misji zagranicznych. Po wprowadzeniu ustawy poszkodowani po urazach bojowych mogli już trafiać do szpitali wojskowych, na przykład przy ulicy Szaserów w Warszawie, gdzie mogą 
liczyć na kompleksową pomoc, w dodatku poza kolejnością. Można powiedzieć, że wprowadzenie tej ustawy było krokiem milowym poprawiającym egzystencję wielu poszkodowanych w czasie działań bojowych poza granicami kraju. Uprawnienia te pozwalają na godniejsze życie ludziom, którzy ojczyźnie poświęcili swe zdrowie.

\section{Bibliografia}

Ustawa z dnia 19 sierpnia 2011 r. o weteranach działań poza granicami państwa, Dz.U. z 2011 r. $\mathrm{Nr} 205$, poz. 1203.

Zapałowski L. (1989), Operacje pokojowe ONZ, Kraków. 